\title{
Governance: Governance Indicators in Nursing Faculty, Benha University
}

Abdel-Rahim S. Shoulah, Sabry A. Salem, Hala A. Abed Hassen, Hoda S. Abd El-Hamid*, Omyma M. Hassen

Department of Community Medicine, Faculty of Medicine, Benha University, Benha, Egypt

*Corresponding author: Hoda S. Abd El-Hamid, Mobile: (+20) 01275478932, E-Mail: hoda.saad2018@ yahoo.com

\begin{abstract}
Introduction: Governance is the system through which the organization's work is directed and monitored at the highest level in order to achieve its objectives and to meet the standards of responsibility, integrity and openness.

Objectives: To determine the degree of practice of the principles of governance in the of nursing faculty from viewpoint of its faculty members, administrative staff and students. Subjects and Methods: This descriptive cross sectional study was conducted to assess the degree of practicing the principles of governance at University College of Nursing in Benha from the viewpoint of its faculty members, administrative staff and students. Data were collected using a questionnaire formed of 83 questions to staff member, administrators and students.

Results: This study finding illustrated that $60.0 \%$ of staff members, $62.6 \%$ of administrators and $59.2 \%$ of students had their knowledge about governance in Benha Faculty of Nursing regarding total items.

Conclusion: There is no statistically significant difference between staff member, administrators and students regarding their score of knowledge about total transparency, total participation and total rule of law. However difference between staff member, administrators and students regarding their score of knowledge about total accountability, total strategic vision and total efficiency and excellence are of statistically significant importance.
\end{abstract}

Keywords: Governance, Knowledge, Staff member, Administrators, Students, BUH.

\section{INTRODUCTION}

Good governance plays an important role throughout the world. Recently there has been much debate about good governance and its role in development in terms of improving economic performance and financial investment ${ }^{(\mathbf{1})}$. Good governance represents one of the most important requirements to achieve development in all societies, especially in developing countries. These countries are now in a dire need of making some serious reforms in their political, economic, social, and administrative structures in order to be able to provide the necessary services for their citizens and help them fulfill their aspirations ${ }^{(2)}$.

Governance is a set of mechanisms, procedures, laws, systems and decisions that ensure discipline, transparency and fairness. Thus, aiming to achieve quality and excellence in performance by activating the management's actions with regard to exploiting the economic resources available to it, stakeholders and society as a whole ${ }^{(3)}$. The principles of good governance such as participation, rule of law, transparency, accountability, fairness and efficiency enable employees to be more effective and transparent in providing high quality services. It also protects them from the tendency towards misconduct ${ }^{(4)}$.

The concept of the governance of education in terms of universities, colleges and all educational institutions has recently emerged as a concept to try to reform university education in all foreign countries, including Arab countries ${ }^{(5)}$.

\section{Objectives:}

To find out the degree of practicing of the principles of governance at Nursing Faculty, Benha University from the viewpoint of its faculty members, administrative staff and students to identify the possible ways to develop it.

\section{SUBJECTS AND METHODS}

Sample of this descriptive cross sectional study was chosen using first: Cluster random sampling to choose one student section from each academic year. Second: Stratified random sample of faculty members and administrative staff according to the academic grade and experience years respectively. Data were gathered using a questionnaire formed of 83 questions to staff member, administrators and students.

\section{Sample}

Epiinfo $^{\text {TM }}$ software, Version 3.4.3 is used to calculate the least required sample size at 0.05 alpha error and $80 \%$ power of the study and population size. Using the proportion of practicing governance $(69.48 \%)$ among faculty members obtained from previous study in Gaza. The least number is 316. After adjusting for $20 \%$ dropout a sample size of 400 was suggested.

\section{Tool of data collection:}

Governance Indicators in Nursing Faculty, Benha University included 2 parts as follow:

Part 1: Personal and work-related data: Gender, sex, type of work, degree, and years of service

Part 2: Assessment of staff members, administrators and students about governance: The questionnaires for staff member, administrators and students are formed of 83 questions. The total score of them ranged from (1-5), (1) strongly disagree, (2) disagree, (3) natural, (4) agree and (5) strongly agree. After modification the total score of them ranged from (1-3), (1) for strongly disagree and disagree, (2) for 
natural and (3) for agree and strongly agree. The score of staff members, administrators and students knowledge about application of governance is considered good if the score equal to or higher than $75 \%$, from $(60 \%-75 \%)$ is considered fair and if less than $60 \%$ is poor ${ }^{(6)}$.

\section{Ethical Consideration: An official permission has been obtained from the Dean of Benha Faculty of Medicine and the Dean of Benha Faculty of Nursing to conduct this study.}

\section{Statistical analyses}

All statistical analyses were carried out using the computerized Statistical Package for Social Science (SPSS, version 20). Quantitative data were tested for normality using Kolmogorov-Smirnov test, if p-value > 0.05 data were considered normally distributed. Qualitative data were demonstrated in terms of frequency and percentage. Quantitative data were summarized as mean \pm standard deviation (SD) for normally distributed data, median and range for nonnormally distributed data. P-value $\leq 0.05$ was considered statistically significant (S), while a p-value $>0.05$ was considered statistically non-significant and a p-value $<0.001$ was considered highly significant (H.S) in all analyses.

\section{RESULTS}

Table (1) showed that more than half of the studied group were females $(62.2 \%)$, while only $(37.8 \%)$ were males. Most of administrators (54.7\%) have experience from 5-10 years, while most of staff member (44\%) have experience more than 10 years. Most of administrators (78.8\%) have educational level of Bachelor's degree, while nearly half of staff member (44\%) have educational level of MD. Less than half of staff member attended lecture (34.7\%), while fewer number of administrators attended lecture (13.3\%).

Table (1): Frequency distribution of studied samples regarding socio-demographic characteristics

\begin{tabular}{|c|c|c|c|c|c|c|}
\hline & \multicolumn{2}{|c|}{$\begin{array}{c}\text { Administrators } \\
(75)\end{array}$} & \multicolumn{2}{|c|}{$\begin{array}{l}\text { Students } \\
(250)\end{array}$} & \multicolumn{2}{|c|}{$\begin{array}{c}\text { Staff member } \\
(75)\end{array}$} \\
\hline & No & $\%$ & no & $\%$ & No & $\%$ \\
\hline \multicolumn{7}{|l|}{ Sex } \\
\hline Female & 42 & 56.0 & 132 & 52.8 & 75 & 100.0 \\
\hline Male & 33 & 44.0 & 118 & 47.2 & 0 & 0.0 \\
\hline Mean age & \multicolumn{2}{|c|}{$34.80 \pm 3.507$} & \multicolumn{2}{|c|}{$19.84 \pm 1.470$} & \multicolumn{2}{|c|}{$32.15 \pm 4.599$} \\
\hline \multicolumn{7}{|l|}{ Experience } \\
\hline$<5$ & 12 & 16.0 & & & 19 & 25.3 \\
\hline From $5-10$ & 41 & 54.7 & & & 23 & 30.7 \\
\hline$>10$ & 22 & 29.3 & & & 33 & 44.0 \\
\hline \multicolumn{7}{|l|}{ Educational level } \\
\hline Intermediate education & 11 & 14.7 & & & 0 & 0.0 \\
\hline Bachelor s degree & 59 & 78.7 & & & 21 & 28.0 \\
\hline Master & 5 & 6.7 & & & 21 & 28.0 \\
\hline MD & 0 & 0.0 & & & 33 & 44.0 \\
\hline \multicolumn{7}{|l|}{ Lecture } \\
\hline No & 65 & 86.7 & 250 & 100.0 & 49 & 65.3 \\
\hline Yes & 10 & 13.3 & 0 & 0.0 & 26 & 34.7 \\
\hline
\end{tabular}

Table (2) indicated that staff members have good knowledge about all items of governance with high percentage $(69.3 \%)$ regarding total strategic vision, and low percentage $(54.7 \%)$ regarding total efficiency.

Table (2): Frequency distribution of studied staff regarding total governance

\begin{tabular}{|l|c|c|c|c|c|c|}
\hline \multirow{2}{*}{} & \multicolumn{2}{|c|}{ Good } & \multicolumn{2}{c|}{ Fair } & \multicolumn{2}{c|}{ Poor } \\
\cline { 2 - 7 } & No & \% & No & \% & No & \% \\
\hline Total Transparency & 46 & 61.3 & 21 & 28.0 & 8 & 10.7 \\
\hline Total accountability & 48 & 64.0 & 19 & 25.3 & 8 & 10.7 \\
\hline Total Participation & 43 & 57.3 & 21 & 28.0 & 11 & 14.7 \\
\hline total Rule of law & 49 & 65.3 & 19 & 25.3 & 7 & 9.4 \\
\hline Total Strategic vision & 52 & 69.3 & 17 & 22.7 & 6 & 8.0 \\
\hline Total Efficiency & 41 & 54.7 & 20 & 26.7 & 14 & 18.6 \\
\hline Total & 47 & 62.6 & 20 & 26.7 & 8 & 10.7 \\
\hline
\end{tabular}


Table (3) illustrated that administrators had good knowledge about all items of governance with high fraction (66.7\%) regarding total strategic vision, and low fraction (57.3\%) regarding total Efficiency.

Table (3): Frequency distribution of studied administrator regarding total governance

\begin{tabular}{|l|c|c|c|c|c|c|}
\hline \multirow{2}{*}{ Total Transparency } & \multicolumn{2}{|c|}{ Good } & \multicolumn{2}{c|}{ Fair } & \multicolumn{2}{c|}{ Poor } \\
\cline { 2 - 7 } & No & $\mathbf{\%}$ & No & \% & No & $\%$ \\
\hline Total accountability & 44 & 58.6 & 24 & 32.0 & 7 & 9.4 \\
\hline Total Participation & 49 & 65.3 & 18 & 24.0 & 8 & 10.7 \\
\hline total Rule of law & 46 & 61.3 & 19 & 25.3 & 10 & 13.4 \\
\hline Total Strategic vision & 48 & 64.0 & 19 & 25.3 & 8 & 10.7 \\
\hline Total Efficiency & 50 & 66.7 & 20 & 26.7 & 5 & 6.6 \\
\hline Total & 43 & 57.3 & 21 & 28.0 & 11 & 14.7 \\
\hline
\end{tabular}

Table (4) demonstrated that students had good knowledge about all items of governance with high score (62.8\%) regarding total strategic vision, and lower score (54.0\%) regarding total efficiency.

Table (4): Frequency distribution of studied students regarding total governance

\begin{tabular}{|l|c|c|c|c|c|c|}
\hline \multirow{2}{*}{} & \multicolumn{2}{|c|}{ Good } & \multicolumn{2}{c|}{ Fair } & \multicolumn{2}{c|}{ Poor } \\
\cline { 2 - 7 } & No & $\mathbf{\%}$ & No & $\mathbf{\%}$ & No & \% \\
\hline Total Transparency & 152 & 60.8 & 60 & 24.0 & 38 & 15.2 \\
\hline Total accountability & 150 & 60.0 & 66 & 26.4 & 34 & 13.6 \\
\hline Total Participation & 150 & 60.0 & 68 & 27.2 & 32 & 12.8 \\
\hline total Rule of law & 155 & 62.0 & 64 & 25.6 & 31 & 12.4 \\
\hline Total Strategic vision & 157 & 62.8 & 64 & 25.6 & 29 & 11.6 \\
\hline Total Efficiency & 135 & 54.0 & 67 & 26.8 & 48 & 19.2 \\
\hline Total & 148 & 59.2 & 67 & 26.8 & 35 & 14.0 \\
\hline
\end{tabular}

Table (5) showed that $61.3 \%$ of staff members had good knowledge about transparency. However, $58.6 \%$ of administrators had good knowledge about it, while $60.8 \%$ of students had good knowledge about it. There was no statistically significant difference among studied groups regarding total transparency.

Table (5): Comparison between studied samples regarding total transparency

\begin{tabular}{|c|c|c|c|c|c|c|c|c|}
\hline & \multicolumn{2}{|c|}{ Staff members } & \multicolumn{2}{|c|}{ administrators } & \multicolumn{2}{|c|}{ students } & $\mathrm{X}^{2}$ & p-value \\
\hline & No & $\%$ & No & $\%$ & No & $\%$ & \multirow{4}{*}{3.53} & \multirow{4}{*}{0.47} \\
\hline Good & 46 & 61.3 & 44 & 58.6 & 152 & 60.8 & & \\
\hline Fair & 21 & 28.0 & 24 & 32.0 & 60 & 24.0 & & \\
\hline Poor & 8 & 10.7 & 7 & 9.4 & 38 & 15.2 & & \\
\hline
\end{tabular}

Table (6) illustrated that $64.0 \%$ of staff members had good knowledge about accountability. However, $65.3 \%$ of administrators had good knowledge about it, while $60.0 \%$ of students had good knowledge about it. There was statistically significant difference among studied groups regarding total accountability.

Table (6): Comparison between studied samples regarding total accountability

\begin{tabular}{|c|c|c|c|c|c|c|c|c|}
\hline & \multicolumn{2}{|c|}{ Staff members } & \multicolumn{2}{|c|}{ administrators } & \multicolumn{2}{|c|}{ students } & $\mathrm{X}^{2}$ & p-value \\
\hline & No & $\%$ & No & $\%$ & No & $\%$ & \multirow{4}{*}{11.12} & \multirow{4}{*}{$0.038 *$} \\
\hline Good & 48 & 64.0 & 49 & 65.3 & 150 & 60.0 & & \\
\hline Fair & 19 & 25.3 & 18 & 24.0 & 66 & 26.4 & & \\
\hline Poor & 8 & 10.7 & 8 & 10.7 & 34 & 13.6 & & \\
\hline
\end{tabular}

Table (7) indicated that $57.3 \%$ of staff members had good knowledge about participation and responsiveness. However, $61.3 \%$ of administrators had good knowledge about it, while $60.0 \%$ of students had good knowledge about it. There was no statistically difference among studied groups regarding total participation and responsiveness.

Table (7): Comparison between studied samples regarding total participation and responsiveness

\begin{tabular}{|c|c|c|c|c|c|c|c|c|}
\hline & \multicolumn{2}{|c|}{ Staff members } & \multicolumn{2}{|c|}{ Administrators } & \multicolumn{2}{|c|}{ Students } & $\overline{X^{2}}$ & p-value \\
\hline & No & $\%$ & No & $\%$ & No & $\%$ & \multirow[b]{4}{*}{0.36} & \multirow[b]{4}{*}{0.98} \\
\hline Good & 43 & 57.3 & 46 & 61.3 & 150 & 60.0 & & \\
\hline Fair & 21 & 28.0 & 19 & 25.3 & 68 & 27.2 & & \\
\hline Poor & 11 & 14.7 & 10 & 13.4 & 32 & 12.8 & & \\
\hline
\end{tabular}


Table (8) illustrated that $65.3 \%$ of staff members had good knowledge about rule of law. However, $64.0 \%$ of administrators had good knowledge about it, while $62.0 \%$ of students had good knowledge about it. There was no statistically significant difference among studied groups regarding total rule of law.

Table (8): Comparison between studied samples regarding total rule of law

\begin{tabular}{|c|c|c|c|c|c|c|c|c|}
\hline & \multicolumn{2}{|c|}{ Staff members } & \multicolumn{2}{|c|}{ administrators } & \multicolumn{2}{|c|}{ students } & $\mathrm{X}^{2}$ & p-value \\
\hline & no & $\%$ & no & $\%$ & no & $\%$ & \multirow{4}{*}{0.64} & \multirow{4}{*}{0.95} \\
\hline Good & 49 & 65.3 & 48 & 64.0 & 155 & 62.0 & & \\
\hline Fair & 19 & 25.3 & 19 & 25.3 & 64 & 25.6 & & \\
\hline Poor & 7 & 9.4 & 8 & 10.7 & 31 & 12.4 & & \\
\hline
\end{tabular}

Table (9) showed that $69.3 \%$ of staff members had good knowledge about strategic vision. However, $66.7 \%$ of administrators had good knowledge about it, while $62.8 \%$ of students have good knowledge about it. There was statistically significant difference among studied groups regarding total strategic vision.

Table (9): Comparison between studied samples regarding total strategic vision

\begin{tabular}{|c|c|c|c|c|c|c|c|c|}
\hline & \multicolumn{2}{|c|}{ Staff members } & \multicolumn{2}{|c|}{ Administrators } & \multirow{2}{*}{$\begin{array}{c}\text { Students } \\
\text { No } \\
\end{array}$} & \multirow[b]{2}{*}{$\%$} & $\mathbf{X}^{2}$ & p-value \\
\hline & No & $\%$ & No & $\%$ & & & \multirow{4}{*}{12.47} & \multirow{4}{*}{$0.035^{*}$} \\
\hline Good & 52 & 69.3 & 50 & 66.7 & 157 & 62.8 & & \\
\hline Fair & 17 & 22.7 & 20 & 26.7 & 64 & 25.6 & & \\
\hline Poor & 6 & 8.0 & 5 & 6.6 & 29 & 11.6 & & \\
\hline
\end{tabular}

Table (10) illustrated that $54.7 \%$ of staff members had good knowledge about efficiency and excellence. However, $57.3 \%$ of administrators had good knowledge about it, while $54.0 \%$ of students had good knowledge about it. There was statistically significant difference among studied samples regarding total efficiency and excellence.

Table (10): Comparison between studied samples regarding total efficiency and excellence

\begin{tabular}{|c|c|c|c|c|c|c|c|c|}
\hline & \multicolumn{2}{|c|}{ Staff members } & \multicolumn{2}{|c|}{ Administrators } & \multicolumn{2}{|c|}{ students } & \multirow[t]{2}{*}{$\mathbf{X}^{2}$} & \multirow[t]{2}{*}{ p-value } \\
\hline & No & $\%$ & No & $\%$ & No & $\%$ & & \\
\hline Good & 41 & 54.7 & 43 & 57.3 & 135 & 54.0 & \multirow[b]{3}{*}{10.81} & \multirow[b]{3}{*}{$0.045^{*}$} \\
\hline Fair & 20 & 26.7 & 21 & 28.0 & 67 & 26.8 & & \\
\hline Poor & 14 & 18.6 & 11 & 14.7 & 48 & 19.2 & & \\
\hline
\end{tabular}

Table (11) revealed that $60.0 \%$ of staff members, $62.6 \%$ of administrators and $59.2 \%$ of students had good knowledge about governance. There was no statistically differences between total governance among studied groups.

Table (11): Comparison between total governance among studied groups

\begin{tabular}{|c|c|c|c|c|c|c|c|c|}
\hline & \multicolumn{2}{|c|}{ Staff members } & \multicolumn{2}{|c|}{ Administrators } & \multicolumn{2}{|c|}{ Students } & $\mathrm{X}^{2}$ & p-value \\
\hline & no & $\%$ & no & $\%$ & no & $\%$ & \multirow{4}{*}{1.10} & \multirow{4}{*}{0.89} \\
\hline Good & 45 & 60.0 & 47 & 62.6 & 148 & 59.2 & & \\
\hline Fair & 18 & 24.0 & 20 & 26.7 & 67 & 26.8 & & \\
\hline Poor & 12 & 16.0 & 8 & 10.7 & 35 & 14.0 & & \\
\hline
\end{tabular}

\section{DISCUSSION}

There are many studies have discussed governance knowledge and practices in Egypt and worldwide. This study aimed at assessing knowledge of staff member, administrators and students about governance indicators in Benha Faculty of Nursing. The current study was conducted on staff members, administrators and students working on Benha Faculty of Nursing. This study illustrated that $60.0 \%$ of staff members, $62.6 \%$ of administrators and $59.2 \%$ of students had their knowledge about governance regarding total items. These results are in accordance with Negm (7) who reported that $69.48 \%$ had knowledge about total items of governance. Moreover, Bassam and Muslim ${ }^{(8)}$, in descriptive and analytical study carried out in Yemen, showed that $71.2 \%$ had knowledge about governance.

As regards transparency, $61.3 \%$ of staff members, $58.6 \%$ of administrators and $60.8 \%$ of students were familiar with the term transparency with good degree. This is in agreement with Negm ${ }^{(7)}$ in Gaza who revealed that $70.19 \%$ of the studied group were familiar with the term transparency. In addition, Nassar ${ }^{(9)}$ reported that transparency came second with high degree $74.72 \%$. On the other hand, this result finding disagrees with Worku ${ }^{(\mathbf{1 0})}$ who undertaken on purposively selected 11 public institutions out of 25 institutions.

In accountability, our study showed that $64.0 \%$ of staff members, $65.3 \%$ of administrators and $60.0 \%$ 
of students were familiar with the term accountability with good degree. The findings of the current study are in accordance with Alagha and Aldahouk (11) who discovered that $82.2 \%$ of participants were familiar with the term accountability. In addition, these results are supported by Ataphia ${ }^{(\mathbf{1 2})}$ who revealed that the degree of application of accountability was very high. Along with El- Nabati ${ }^{(\mathbf{1 3})}$ who demonstrated that there was a commitment to accountability in his study, which aimed to determine the degree of management leadership practice in the areas of accountability at a university in Mecca. Besides, Negm (7) found that accountability ranked first by a percentage of $70.47 \%$. This can be explained by that the University seeks to ensure the conduct of its internal and external operations. That why it uses a strong accountability system to maintain its progress and achieve their goals. On the other hand, this result finding disagrees with ElArini ${ }^{(14)}$ who recommended the issuance of regulations and legislation related to the principles of university governance, and the obligation of departments and councils within the university to work in them, establishing independent committees within the university to follow up the implementation of governance standards.

Concerning, participation and responsiveness, this study showed that $57.3 \%$ of staff members, $61.3 \%$ of administrators and $60.0 \%$ of students were familiar with the term of participation and responsiveness. These results are consistent with Massey and Field ${ }^{(15)}$ who found that participation and responsiveness were highly applied. On the other hand, Nasbah ${ }^{(6)}$ found that only $33.0 \%$ of participated were familiar with term participation, however $60.0 \%$ of participated were not familiar with this term due to that the University still lacks the means to engage in dialogue and participation, which is linked to the lack of great adoption of the method working with a team.

As regards rule of law, justice and equality in this study, $65.3 \%$ of staff members, $64.0 \%$ of administrators and $62.0 \%$ of students were familiar with the term of rule of law, justice and equality. Along with this, Nasbah ${ }^{(6)}$ demonstrated that the majority of studied group $(45 \%)$ respected the law and agreed with this indicator. However, only $14 \%$ disagreed with rule of law. This is due to that the University is working to apply the law to everyone without exception. However, there are still some cases of discrimination between the two in the treatment and application of the law especially in terms of administrative position between the ordinary employee and officials in senior positions. This result finding disagrees with El-Arini ${ }^{(14)}$ who revealed that less than half $(39.2 \%)$ were familiar with the term of rule of law, justice and equality. This recommended the issuance of regulations and the principles of university governance, and the obligation of departments and councils within the university to work with them. Thus, establishing independent committees within the university to follow up the implementation of governance standards ${ }^{(14)}$.

As regards strategic vision in the current study, $69.3 \%$ of staff members, $66.7 \%$ of administrators and $62.8 \%$ of students were familiar regarding strategic vision. Similarly, El Refae ${ }^{(\mathbf{1 6})}$ stated that nearly half of the studied group $45.93 \%$ were familiar with strategic vision. While Nasbah ${ }^{(6)}$ found that $57.0 \%$ of the studied group had their knowledge about strategic vision, while $38 \%$ disagreed with this indicator. This is because the University is working to develop strategic plans and work to achieve them, but the most important in this is the presence of continuous assessment and follow-up and rationalization of expenses and time and effort. The University is working to develop programs and objectives as planned. This may be due to the availability of funding. There is also a lack of cooperation among all parties to achieve these objectives due to the overriding interest of some of them.

In this study, $54.7 \%$ of staff members, $57.3 \%$ of administrators and $54.0 \%$ of students were familiar with the term of rule of law, justice and equality. The result is coordinated with El-Arini ${ }^{(14)}$ who revealed that there were attempts by the university to develop work and performance for its organizers. However, it did not reach its desired limit. This may be due to that staff may not be involved in proposing university goals or vision looking forward to achieve them. This resulted in poor performance and consequently insufficiency in the organizational effectiveness of the university. This also comes with Burqaan and AlQurashi ${ }^{(5)}$ who stated that the university governance leads the university institutions to be able to make a difference how they are managed, and to assess the performance of all their management in a scientific manner ${ }^{(5)}$.

\section{CONCLUSION}

From the present study, it can be concluded that $60.0 \%$ of the staff members, $62.6 \%$ of administrators and $59.2 \%$ of students were familiar with the term governance at Nursing of Benha University.

Our study also revealed that there was no statistically significant difference between staff member, administrators and students regarding their score of knowledge about total transparency, total participation and total rule of law. However, there were statistically significant difference between staff member, administrators and students regarding their score of knowledge about total accountability, total strategic vision, total efficiency and excellence, which are of importance.

\section{RECOMMENDATIONS}

1. The need for officials in the Ministry of Higher Education and Scientific Research to organize training courses to explain to the academic leaders 
in which the concept of governance for the purpose of preparing them and raise the level of governance practice among academics.

2. Continuous evaluation of college plans with a view to develop them.

3. Informing faculty members of their roles.

4. Assigning universities by the Ministry of Higher Education to establish governance boards and others for continuous improvement.

5. Following up the implementation of all agreed laws and regulations without prejudice, and by monitoring the regulations and laws that apply at the university.

6. The need to issue clear rules and regulations, and to adopt the concepts of governance, especially with regard to transparency, accountability and clarity.

7. Solving all problems without bias, by asking for accountability, clarity and transparency.

8. Taking into account the experiences, regulations and laws of other similar and successful universities, which are close to our environment and we can apply them on the ground.

9. Not to increase the number of students in order to increase university income at the expense of the quality of graduating students.

10. That favoritism does not affect the implementation of governance significantly.

\section{ACKNOWLEDGMENT}

We would like to thank the Dean of Benha Faculty of Nursing, staff member, administrators and students working in Benha faculty of Nursing for their invaluable help in this study. This study was supported by a grant from all teamwork.

Conflicting Interest: The author declared that there was no conflict of interest.

\section{REFERENCES}

1. Kurdi F (2016): Good governance and its impact in improving administrative and financial performance: a case study of Nablus Municipality. International Humanities Studies, 3 (4): 30-47.

2. Grindle M (2004): Good enough governance: poverty reduction and reform in developing countries. Governance, 17 (4): 525-548.

3. Alshaer I, Al hila A, Al Shobaki M et al. (2017): Governance of Public Universities and Their Role in Promoting Partnership with Non-Governmental Institutions. International Journal of Engineering and Information Systems, 1 (9): 214-238.

4. Alaaraj H, Ibrahim F (2014): The Influence of E government Practices on good governance from the perspective of Public in Lebanon. Journal of Public Administration and Governance, 4 (3): 171-185.

5. Burqaan A, Al-Qurashi A (2012): The globalization of management in the era of globalization, a paper presented to the International Scientific Conference, Lebanon: Jinan University. http://scholar-google-com443.webvpn.fjmu.edu.cn/scholar?q=Barqa

6. Nasbah S (2015): The importance of applying the principles of governance in the public sector, Master's degree, University of Shaheed Hama Lakhdar, Wadi, Republic of Algeria. https://www.ifac.org/system/files/publications/files/Go od-Governance-in-the-Public-Sector.pdf

7. Negm N (2017): Degree of practice of Governance Principles in the University College of Applied Sciences in Gaza from Staff Perspective and Ways of its Development. Degree of practice of Governance Principles in the University College of Applied Sciences in Gaza from Staff Perspective and Ways of its Development. http://hdl.handle.net/20.500.12358/20520

8. Bassam M (2016): The level of practicing good governance principles in private Yemeni universities: Field study - University of Science and Technology. Journal of Social Studies, 22 (49): 282-233.

9. Nassar S (2017) Evaluating the extent to which the performance of Palestinian universities' administrations in the Gaza Strip conform to the principles of governance and some discrimination criteria Field Study. The Arab Journal of Science and Research Publishing, 3 (1): 42-60.

10. Worku M (2013): Assessment of the Prevalence of Good Governance in Public Sector: the Case of Selected Public Institutions in Addis Ababa City of Ethiopia. Institutional Repository. http://hdl.handle.net/123456789/2779

11. Alagha M, Aldahouk H (2015): The Impact of Personal Variables of UNRWA School Principals on the Estimated Degree of Intelligent Accountability Practice. American Journal of Educational Science, 1 (4): 122134.

12. Ataphia D (2011): An Assessment of Accountability among Teachers in Secondary Schools in Delta State. African Journal of Social Sciences, 1 (1): 115-125.

13. Al-Nabati A (2011): Degree of Administrative Leadership Practice for Accountability at Umm Al-Qura University in Makkah Al-Mukarramah, Unpublished Master Thesis, Umm Al-Qura University, Makkah, Saudi Arabia. https://uqu.academia.edu/Faredah AlMurahhem/CurriculumVitae

14. Al-Arini M (2014): The reality of administrative wisdom and academic staff at Imam Muhammad bin Saud Islamic University. International Specialized Educational Journal, 3 (12): 16-25.

15. Massey J Field S (2015): Can They Teach Each Other?: The Restructuring of Higher Education and the Rise of Undergraduate Student "Teachers" in Ontario. Journal of Critical Scholarship on Higher Education and Student Affairs, 1 (1): 4-16.

16. El Refae G (2017): University Governance: Risk Management Approach. Journal of Business and Law, 1 (1): https://digitalcommons.aaru.edu.jo/aaujbl/vol1/iss1/3 